\title{
STRATEGI PENGEMBANGAN AGROINDUSTRI KERIPIK JAHE (JAHEKU) DI DESA KOTA RAYA KECAMATAN RENGAT KABUPATEN INDRAGIRI HULU
}

\author{
Strategy Development of Agroindustri Flaky Ginger (Jaheku) in Kota Raya \\ Village Rengat District Indragiri Hulu Regency
}

\author{
Novi Dwi Ningsih, Evy Maharani, Shorea Khaswarina \\ Department of Agribusiness, Faculty of Agriculture, University of Riau \\ JL. Binawidya 30, Pekanbaru 28291 \\ novidwiningsih05@gmail.com \\ [Diterima: Agustus 2017; Disetujui: November 2017]
}

\begin{abstract}
Agroindustry as the development of agricultural sector expected can play a part in to create a market to agriculture pickings through various its product of him. The strategy is big scale plan which has future reach priority which far is and also specified in such a manner so that enable organization to have interaction to effectively with its environment in a condition aimed at all emulation optimization attainment of target with a various pertinent organizational target. This research revenue analysis aim to the effort my ginger and compile correct development strategy to a worker of ginger in Kota Raya Village Rengat District Indragiri Hulu Regency. Result of research of Amount produce its month; moon ginger flaky that is 360 bale, whereas in acceptance to the effort my ginger that is Rp. 5.400.000. obtained net earning the effort my ginger Rp. 2.764.000 per month. correct Development strategy to worker of ginger flaky is: Increase product ginger flaky to fulfill request of market, conducting ginger flaky promotion and make more interesting tidiness to be an access to market broader, Maintaining market which has there is and looks for new market by improving opportunity of promotion by following existing exhibition; Braid cooperation with relevant institute to be is tough of capital employed and self-service to market product, managing health permit so that marketing of broader ginger flaky; Take care of the availability of raw material at the time of price of fluctuating and do product continuity by providing raw material stock and avoid too kept old raw material; Improve standard quality of especial raw material, supporter raw material in order not to easy to destroy, and also look for market information through newspaper, on duty commerce and follow existing exhibition, making better product can fulfill request of market.
\end{abstract}

Keyword: Agroindustri, Development, Strategy

\begin{abstract}
ABSTRAK
Agroindustri sebagai penarik pembangunan sektor pertanian diharapkan mampu berperan dalam menciptakan pasar bagi hasil-hasil pertanian melalui berbagai produk olahan. Strategi adalah rencana berskala besar yang berprioritas jangkauan masa depan yang jauh serta ditetapkan sedemikian rupa sehingga memungkinkan organisasi berinteraksi secara efektif dengan lingkungannya dalam kondisi persaingan yang semuanya diarahkan pada optimalisasi pencapaian tujuan dengan berbagai sasaran organisasi yang bersangkutan.Penelitian ini bertujuan menganalisis pendapatan usaha jaheku dan menyusun strategi pengembangan yang tepat bagi pengrajin jaheku di Desa Kota Raya Kecamatan Rengat Kabupaten Indragiri Hulu. Hasil penelitian Jumlah produksi keripik jahe perbulannya yaitu 360 bungkus, sementara dalam penerimaan untuk usaha jaheku yaitu Rp. 5.400.000. Pendapatan bersih yang diperoleh usaha jaheku adalahRp. 2.764 .000 setiap bulannya. Strategi pengembangan yang tepat bagi pengrajin keripik jahe adalah: Meningkatkan produksi keripik jahe untuk memenuhi permintaan pasar, melakukan promosi keripik jahe dan membuat kemasan yang lebih menarik agar dapat memasuki pasar yang lebih luas, Mempertahankan pasar yang sudah ada dan mencari pasar yang baru dengan meningkatkan kesempatan promosi dengan mengikuti pameran yang ada; Menjalin kerjasama dengan lembaga terkait untuk menabah modal usaha dan swalayan-swalayan untuk memasarkan produk, mengurus izin kesehatan agar pemasaran keripik jahe lebih luas; Menjaga ketersediaan bahan baku pada saat harga fluktuatif dan melakukan kontinitas produk dengan
\end{abstract}


menyediakan stok bahan baku dan menghindari bahan baku yang terlalu lama disimpan; Meningkatkan standar mutu bahan baku utama, bahan baku penunjang agar tidak mudah rusak, serta mencari informasi pasar melalui koran, dinas perdagangan, mengikuti pameran yang ada, membuat produk yang lebih baik agar mampu memenuhi permintaan pasar.

Kata kunci: Agroindustri, Strategi, Pengembangan.

\section{PENDAHULUAN}

Pembangunan pertanian diarahkan untuk meningkatkan produksi pertanian guna memenuhi kebutuhan pangan dan kebutuhan industri dalam negeri, meningkatkan ekspor, meningkatkan pendapatan petani, memperluas kesempatan kerja dan mendorong pemerataan kesempatan berusaha. Upaya yang dilakukan untuk mewujudkan sarana pembangunan pertanian yang dimaksud diantaranya yaitu dengan meningkatkan keterampilanmasyarakat yang memadai dalam memantapkan jenis industri pengolahan hasil pertanian yang disertai peningkatan bahan baku secara berkesinambungan. Masyarakat yang dimaksud disini adalah difokuskan pada sebagian masyarakat desa yang merupakan suatu komoditas yang kurang berkembang dibandingkan dengan masyarakat perkotaan.

Jahe dalam keadaan segar tidak tahan lama dan harganya rendah. Namun jika dilakukan pengolahan lebih lanjut dan dikelola secara maksimal menjadi keripik jahe, maka jahe tersebut akan memiliki nilai ekonomis yang lebih tinggi sehingga akan memberikan pendapatan yang cukup besar bagi petani dan masyarakat. Bersamaan dengan hal tersebut akan meningkatkan pula industri-industri pengolahan dengan jahe sebagai bahan baku utamanya. Usaha Jaheku yang terdapat di Kecamatan Rengat ini termasuk kedalam industri rumah tangga. Industri rumah tangga ini belum menunjukkan perkembangan yang signifikan. Proses produksi keripik jahe skala industri rumah tangga secara teknis tidak pernag mengalami kesulitan, beberapa kendala dalam pengembangan agroindustri keripik jahe yaitu dalam hal izin merek dagang, pemasaran yang belum berkembang karena masih di sekitar Kota Rengat saja, peralatan usaha yang masih terbatas untuk kapasitas produksi yang besar, masalah ketersediaan bahan baku jahe pada saat harga naik dan kualitas jahe yang tidak bagus dan faktor pendukung seperti tenaga kerja yang masih kurang. Analisis usaha dan strategi pengembangan perlu dikaji agar usaha keripik jahe yang berada di Kecamatan Rengat dapat berkembang dan dapat melihat kekuatan, kelemahan dan peluang, ancaman yang ada pada usaha keripik jahe untuk mencapai tujuan tersebut.

Permasalahan yang dijumpai dalam agroindustri keripik jahe adalah bagaimana strategi pengembangan yang tepat bagi pengrajin jaheku di Desa Kota Raya Kecamatan Rengat. Agar usaha agroindustri ini mampu bersaing dan berkembang, diperlukan suatu strategi operasional yang tepat. Strategi yang tepat dapat menghasilkan produk yang berkualitas tinggi sehingga nilai jualnya akan lebih tinggi yang pada akhirnya akan mampu mendatangkan keuntungan yang lebih tinggi. Hal ini akan memberikan harapan bagi pengusaha karena peluang pasar produk yang semakin luas dan baik. Adapun tujuan yang ingin dicapai pada penelitian ini adalah; Merumuskan strategi pengembangan yang tepat bagi pengrajin jaheku di Desa kota Raya Kecamatan Rengat Kabupaten Indragiri Hulu.

\section{BAHAN DAN METODE}

Penelitian ini dilaksanakan di Desa Kota Raya Kecamatan Rengat Kabupaten Indragiri Hul pada agroindustri Keripik jahe (jaheku).Penelitian ini terhitung mulai dari bulan Oktober sampai Februari 2017.

Metode yang digunakan dalam penelitian ini adalah studi kasus terhadap usaha jaheku yang terletak di Desa Kota Raya Kecamatan Rengat Kabupaten Indragiri Hulu. Peneliti mengumpulkan data untuk memperoleh informasi yang dibutuhkan dalam rangka mencapai tujuan penelitian. Peneliti mengumpulkan data dan mendeskripsikan proses pembuatan keripik jahe dan masalah yang ada pada usaha jaheku di Desa Kota Raya.

Data yang dikumpulkan dalam penelitian ini terdiri dari data primer dan data sekunder.Data primer diperoleh dari wawancara berdasarkan kuesioner terhadap pengrajin. Data primer yang diambil adalah identitas pengrajin agroindustri (umur, pendidikan, pengalaman agroindustri, tanggungan keluarga), aspek produksi (bahan baku, tenaga kerja, modal, 
manajemen dan bahan penunjang), aspek pengolahan (waktu dan tempat pengolahan, produk, jumlah produksi dan biaya pengolahan), aspek teknologi (teknologi yang digunakan, penguasaan teknologi, pengaruh teknologi terhadap produksi dan pengemasan), aspek pemasaran, aspek kelembagaan (lembaga keuangan, organisasi). Data sekunder diperoleh dari instansi atau lembaga yang terkait, data sekunder dalam penelitian ini antara lain meliputi keadaan umum daerah, jumlah penduduk, keadaan ekonomi sosial penduduk, serta potensi desa terhadap agroindustri yang terdapat di Desa Kota Raya Kecamatan Rengat Kabupaten Indragiri Hulu (Soekartawi, 2005).

Tabel 1. Bagan Matrik SWOT
Data yang diperoleh di lapangan kemudian dianalisis sesuai dengan tujuan penelitian, dalam menganalisis data yang diperoleh dari objek penelitian untuk tujuan penelitian yaitu: Merumuskan strategi pengembangan yang tepat bagi pengrajin jaheku di Desa kota Raya Kecamatan Rengat Kabupaten Indragiri Hulu. Penggunaan analisis SWOT sangat membantu untuk menyusun suatu strategi dengan mengkombinasikan aspek-aspek kekuatan, kelemahan, dalam faktor internal dan dengan aspek-aspek peluang, ancaman pada faktor eksternal. Matrik SWOT ini menghasilkan empat kemungkinan alternatif strategi yaitu : 1) strategi SO; 2) strategi ST; 3) strategi WO; 4) strategi WT.

\begin{tabular}{lll}
\hline & \multicolumn{1}{c}{$\begin{array}{c}\text { Stranghts (S) } \\
\text { Faktor internal }\end{array}$} & \multicolumn{1}{c}{$\begin{array}{c}\text { Weaknesses (W) } \\
\text { Daftar kelemahan }\end{array}$} \\
\hline $\begin{array}{l}\text { Opportunities (O) } \\
\text { Daftar peluang }\end{array}$ & $\begin{array}{l}\text { Strategi (S-O) } \\
\text { Memakai kekuatan untuk } \\
\text { memanfaatkan peluang }\end{array}$ & $\begin{array}{l}\text { Strategi (W-O) } \\
\text { Menanggulangi kelemahan dengan } \\
\text { memanfaatkan peluang }\end{array}$ \\
Threats (T) & Strategi (S-T) & Strategi (W-T) \\
Daftar ancaman & Memakai kekuatan untuk & Memperkecil kelemahan dan \\
& mengatasi ancaman & menghindari ancaman \\
\hline
\end{tabular}

Sumber: Rangkuti (1997)

\section{HASIL DAN PEMBAHASAN}

\section{Aspek-aspek Pada Agroindustri Jaheku A. Aspek Produksi}

Aspek produksi adalah segala aspek yang berkaitan dengan bahan baku utama, bahan baku penunjang, bahan penunjang serta tenaga kerja dan modal. Ketersediaan bahan baku yang kontiniu merupakan faktor utama didalam melakukan suatu kegiatan produksi, baik tersedia secara tepat waktu, kuantitas maupun kualitas sehingga menjamin penampilan perusahaan dalam waktu yang relatif lama (Soekartawi, 2001). Agroindustri keripik jahe adalah kegiatan mengolah jahe segar menjadi bubuk jahe dan bahan baku lainnya seperti wijen, kelapa sangrai dan gula putih dengan beberapa tahapan proses produksi yaitu : tahap pencucian jahe segar, tahap pengirisan jahe Jahe, tahap penjemuran jahe, tahap penggilingan. Bahan baku adalah faktor produksi selain tenaga kerja dan peralatan yang digunakan dalam suatu proses produksi, dimana ketersediaan dan kualitas bahan baku secara kontinu perlu diperhatikan karena akan berpengaruh pada kualitas produk yang dihasilkan (Lestari, 2006). Kegiatan agroindustri selain bahan baku utama juga terdapat bahan penunjang yang digunakan dalam proses produksi walaupun tidak berpengaruh secara langsung pada produk yang akan dihasilkan (Lestari, 2006). Selain bahan baku juga terdapat bahan baku penunjang. Bahan baku penunjang adalah bahan baku yang mutlak digunakan dalam pembuatan keripik, Tanpa bahan penunjang ini, produk akan tetap bisa diselesaikan, hanya saja jadinya tidak akan sesuai dengan yang diharapkan, Serta porsi penggunaan bahan ini lebih kecil dari keseluruhan bahan yang dipakai.Adapun bahan baku yang digunakan dalam agroindustri keripik jahe adalah sebagai berikut: Gula pasir, Wijen, kelapa sangrai dan bubuk jahe.

Keberadaan bahan penunjang sangat diperlukan karena menunjang kegiatan produksi keripik jahe, bahan penunjang yang digunakan dalam proses pembuatan keripik jahe yaitu : Merek, Gas dan kompor gas, Plastik pembungkus, Alat penggiling yang digunakan debok pisang (batang pisang), Gunting. 
Tabel 2. Rataan Penggunaan Bahan Baku Utama, dan Bahan Penunjang Pada Keripik Jahe.

\begin{tabular}{|c|c|c|c|c|c|}
\hline NO & Bahan baku dan bahan penunjang & Total (bln) & $\begin{array}{r}\text { harga } \\
(\mathrm{Rp} / \mathrm{kg})\end{array}$ & $\begin{array}{r}\text { Total biaya } \\
(\mathrm{Rp} / \mathrm{PP})\end{array}$ & $\begin{array}{r}\text { Total biaya } \\
\text { (Rp/ bln) }\end{array}$ \\
\hline \multirow[t]{4}{*}{1} & Bahan baku utama $(\mathrm{Kg})$ & & & & \\
\hline & 1. Bubuk jahe & & & & \\
\hline & 2. Wijen & 4,8 & 30.000 & 3000 & 144.000 \\
\hline & 3. Kelapa sangrai & & & & \\
\hline \multirow[t]{3}{*}{2} & Bahan baku penunjang & & & & \\
\hline & 1. Gula pasir $(\mathrm{Kg})$ & 72 & 12.500 & 2.500 & 900.000 \\
\hline & & Jumlah & & & 1.044 .000 \\
\hline \multirow[t]{6}{*}{3} & Bahan penunjang & & & & \\
\hline & 1. Merek (lembar) & 360 & 200 & & 72.000 \\
\hline & 2. Gas (tabung $12 \mathrm{~kg}$ ) & 1 & 140.000 & & 140.000 \\
\hline & 3. Plastik pembungkus (lembar) & 360 & 500 & & 180.000 \\
\hline & & Jumlah & & & 392.000 \\
\hline & & l Keseluruhan & & & 1.436 .000 \\
\hline
\end{tabular}

Sumber tenaga kerja yang digunakan dalam usaha keripik jahe ini adalah Tenaga Kerja Dalam Keluarga (TKDK) dengan satuannya adalah satu bulan kerja sebesar Rp. 300.000.Penggunaan tenaga kerja lebih banyak terdistribusi pada tenaga kerja wanita hanya untuk kegiatan pembuatan keripik jahe, sedangkan tenaga kerja untuk pemasaran hasil produksi dilakukan oleh pemilik usaha dan suaminya. Penggunaan tenaga kerja wanita lebih banyak dicurahkan waktu kerjanya untuk kegiatan pemasakan dikarenakan proses pemasakan atau pembuatan keripik jahe membutuhkan ketekunan dalam mengolah keripik jahe.

Tabel 3.Rataan Penggunaan Tenaga Kerja Dalam Keluarga Pada Usaha Keripik Jahe.

\begin{tabular}{|c|c|c|c|c|c|c|}
\hline \multirow[b]{2}{*}{ No } & \multirow[b]{2}{*}{ KEGIATAN } & \multirow{2}{*}{$\begin{array}{c}\text { JUMLAH } \\
\text { TK } \\
\text { (ORANG) }\end{array}$} & \multicolumn{4}{|c|}{ TENAGA KERJA DALAM KELUARGA } \\
\hline & & & $\begin{array}{c}\text { Pria } \\
\text { (bks) }\end{array}$ & $\begin{array}{c}\text { Upah } \\
\text { (Rp/bln) }\end{array}$ & $\begin{array}{c}\text { Wanita } \\
\text { (bks) }\end{array}$ & $\begin{array}{c}\text { Upah } \\
\text { (Rp/bln) }\end{array}$ \\
\hline 1. & $\begin{array}{l}\text { Pengolahan dan pengemasan keripik } \\
\text { jahe }\end{array}$ & 3 & & & 90 & 300.000 \\
\hline 2. & Pemasaran keripik jahe & 1 & 90 & 300.000 & & \\
\hline & Jumlah & 4 & 90 & 300.000 & 90 & 300.000 \\
\hline
\end{tabular}

\section{B. Aspek Pengolahan}

Aspek pengolahan meliputi tempat pengolahan, produk, jumlah produksi, dan biaya pengolahan, ketersediaan tempat pengolahan keripik jahe cukup besar dan bersih. Jumlah produksi keripik jahe cukup besar dan keripik jahe memiliki cita rasa khas jahe, disini pengrajin juga menghitung biaya pengolahan keripik jahe. Waktu pengolahan keripik jahe di mulai pukul 08:00 sampai dengan pukul 12:00 WIB, Tahap pembuatan dan pengemasan keripik jahe yaitu tahap awal pembuatan keripik jahe adalah kita masukan gula putih kedalam wajan atau teflon sampai mencair atau sampai menjadi karamel kemudian masukan bubuk jahe yang sudah dicampur dengan wijen dan kelapa parut yang sudah di sangrai sebelumya. Kemudian di aduk- aduk menggunakan adukan kayu, setelah itu angkat dan letakan di plastik yang sudah di sediakan sebelumnya dimeja kemudian diratakan menggunakan glilingan dari debok pisang yang kecil sampai ketipisan yang diinginkan, kemudian gunting segi empat adonan tadi lalu digulung (ingat gulungnya selagi panas, karena jika sudah dingin maka adonan mengeras dan susah di gulung dan akan pecah). Selanjutnya tahapan pengemasan ini dilakukan dengan menggunakan plastik tebal dan kemudian di pres menggunakan mesin agar tahan lama, namun pengemasan yang menggunakan plastik tebal ini sudah memiliki 
merek dagang. Pembuatan dan pengemasan keripik jahe dilakukan oleh 4 orang tenaga kerja.

\section{Aspek Teknologi}

Produksi pertanian tidak dapat meningkatkan bila pelaksanaannya tidak menguasai teknologi. Seperti pernah pula disarankan oleh Moshar (1996) dalam Soekartawi (2005), bahwa penguasaan teknologi pertanian yang senantiasa berubah ini, merupakan syarat mutlak dalam keberhasilan pembangunan pertanian. Aspek teknologi meliputi teknologi yang digunakan, penguasaan teknologi, dan pengemasan, teknologi tradisional digunakan ditingkat pengrajin yaitu dengan menggunakan peralatan yang sangat sederhana, penggunaan alat sederhana ini berpengaruh pada kapasitas produksi dan mutu yang relatif rendah. Rendahnya pengetahuan dan penggunaan teknologi oleh pengrajin disebabkan masih rendahnya kualitas sumberdaya manusia pelaku agroindustri dan kurang tersedianya teknologi dan peralatan pengolahan secara merata oleh dinas-dinas terkait. Peralatan (teknologi) yang digunakan dalam pembuatan keripik jahe adalah sebagai berikut: kompor gas, teflon (wajan kecil), spatula (sutil), spatula sayur (sendok sayur), tabung gas $3 \mathrm{~kg}$, toples besar, spatula plastik (solet plastik), box plastik container, pengepres plastik. Adapun biaya penyusutan peralatan yang digunakan sebanyak 12 unit dengan nilai penyusutan setiap bulannya sebesar Rp. 8678,39 dapat dilihat pada tabel 4 .

Tabel 4. Biaya Penyusutan Peralatan Pada Pembuatan Keripik Jahe Pada Bulan Desember 2015.

\begin{tabular}{clcrrr}
\hline No & Uraian Barang & Unit & Harga/unit & UE (bln) & Nilai Penyusutan (bln) \\
\hline 1 & Kompor Gas & 1 & 325.000 & 144 & $1.805,56$ \\
2 & Teflon (wajan) & 1 & 156.000 & 98 & $1.273,47$ \\
3 & Spatula (sutil) & 1 & 28.000 & 60 & 373,33 \\
4 & Spatula sayur & 2 & 16.000 & 60 & 426,67 \\
5 & Tabung gas 3 kg & 1 & 180.000 & 72 & $2.000,00$ \\
6 & Toples besar & 2 & 52.000 & 84 & 990,48 \\
7 & Spatula (solet plastik) & 3 & 6.000 & 12 & $1.200,00$ \\
8 & box plastik container & 1 & 137.000 & 180 & 608,89 \\
9 & pengepres plastik & 1 & 450.000 & 60 & $6.000,00$ \\
\hline & Jumlah & 12 & 900.000 & 710 & $8.678,39$ \\
\hline & Rata-rata & 1,5 & 100.000 & 78,89 & $1.084,80$ \\
\hline
\end{tabular}

\section{Aspek Pemasaran}

Pemasaran merupakan hal yang sangat penting dalam suatu usaha, karena pasar merupakan tempat dimana para pengrajin menjual hasil produksinya untuk memenuhi kebutuhan sehari-hari. Sehingga efisiensi biaya pemasaran seperti biaya transportasi dan biaya pengemasan perlu dilakukan dan pada akhirnya dapat peluang untuk menembus pasar yang lebih luas dan bukan hanya dalam ruang lingkup kota rengat saja. jumlah permintaan terhadap keripik jahe cenderung stabil, dilihat dari produk keripik jahe yang selalu habis terjual di swalayan-swalayan.

\section{E. Aspek Kelembagaan}

Suatu usaha terutama usaha kecil atau industri rumah tangga perlu ditunjang oleh aspek kelembagaan, disini peran pemerintah dalam membimbing serta mengarahkan para pengrajin sangatlah diperlukan. Baik itu mengenai bantuan teknis maupun konsultasi pada usaha yang berbasis keluarga demi meningkatkan pengetahuan, kemampuan dalam manajemen serta motivasi kepada pengrajin keripik jahe. Disini pengrajin menggunakan modal sendiri tidak meminjam atau bekerjasama dengan lembaga keuangan seperti Bank, Koperasi dan sebagainya. Peranan dan tugas koperasi Indonesia ialah membengun ekonomi dan mengembangkan kesejahteraan anggota pada khususnya dan masyarakat pada umumnya (Sudarsono, 2002). Jika koperasi dapat dikembangkan di lingkungan pengrajin, maka akan sangat membantu terhadap pengrajin, terutama dalam menjamin modal. Lemahnya pembinaan dan penerapan jaminan mutu mempunyai 
andil terhadap rendahnya mutu produk yang dihasilkan agroindustri (Susilo, 2008).

\section{Analisis SWOT Agroindustri Keripik Jahe}

Analisis SWOT adalah identifikasi dari berbagai faktor kekuatan (strengths), kelemahan (weaknesses), peluang (oportunities) dan ancaman (threats) secara sistematis untuk merumuskan strategi perusahaan.Analisis SWOT didasarkan pada asumsi bahwa strategi yang paling efektif adalah memaksimalkan kekuatan dan peluang yang dimiliki oleh agroindustri serta meminimalkan kelemahan dan ancaman yang dihadapi.

Tabel 5. Matrik SWOT Agroindustri Keripik Jahe

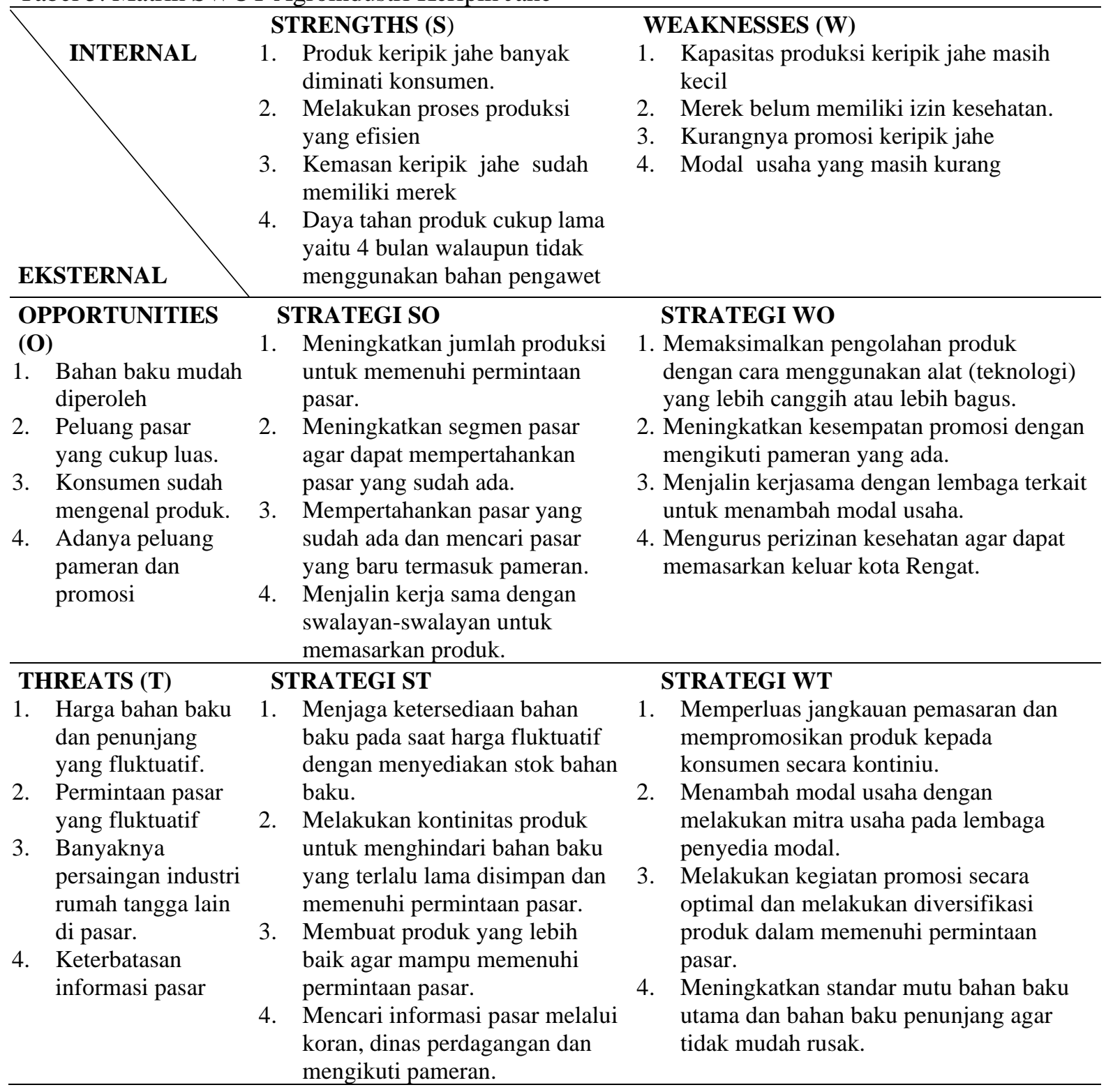

Tabel 6. Pengembangan Unsur-unsur SWOT

\begin{tabular}{cccccccc}
\hline \multicolumn{2}{c}{ Kekuatan (S) } & \multicolumn{2}{c}{ Kelemahan $(\mathrm{W})$} & \multicolumn{2}{c}{ Peluang $(\mathrm{O})$} & \multicolumn{2}{c}{ Ancaman (T) } \\
\hline S1 & 3 & W1 & 1 & O1 & 3 & T1 & 3 \\
S2 & 2 & W2 & 1 & O2 & 3 & T2 & 2 \\
S3 & 2 & W3 & 2 & O3 & 2 & T3 & 2 \\
S4 & 3 & W4 & 2 & O4 & 2 & T4 & 3 \\
\hline
\end{tabular}


Tabel 7. Alternatif Pemilihan Strategi Pengembangan Usaha jaheku

\begin{tabular}{llcc}
\hline \multicolumn{1}{c}{ Unsur SWOT } & \multicolumn{1}{c}{ Keterkaitan } & Bobot & Ranking \\
\hline SO1 & S1, S2, S3, S4, O1, O2, O3, O4 & 20 & 1 \\
SO2 & S1, S2, S3, S4,O1,O2, O3 & 18 & 2 \\
SO3 & S1, S3, S4, O2, O3, O4 & 15 & 4 \\
SO4 & S1, S3, S4, O2, O3, O4 & 15 & 4 \\
WO1 & W1,W2,W3,O1,O2,O4 & 12 & 6 \\
WO2 & W3,W4,O2,O3,O4 & 11 & 7 \\
WO3 & W1, W3, W4, O2, O3, O4 & 12 & 6 \\
WO4 & W1,W2,W3,W4, O2,O3,O4 & 13 & 2 \\
ST1 & S1,S2,S3,S4, T1, T2, T4 & 18 & 5 \\
ST2 & S1,S2, S4, T2,T4 & 13 & 4 \\
ST3 & S1, S3, S4, T2, T3,T4 & 15 & 2 \\
ST4 & S1,S3,S4, T1,T2,T3,T4 & 18 & 3 \\
WT1 & W1,W2,W3,W4,T1,T2,T3,T4 & 16 & 3 \\
WT2 & W1,W2,W3,W4,T1,T2,T3,T4 & 16 & 7 \\
WT3 & W1,W2,W3,T2,T3,T4 & 11 & 6 \\
WT4 & W1,W2,W4,T1, T2, T4 & 12 & 7 \\
\hline
\end{tabular}

Berdasarkan nilai pembobotan yang telah dilakukan, maka dapat ditentukan alternatif strategi pengembangan yang dapat diterapkan oleh pengusaha sebagai berikut :

1. Meningkatkan produksi keripik jahe untuk memenuhi permintaan pasar, melakukan promosi keripik jahe dan membuat kemasan yang lebih menarik agar dapat memasuki pasar yang lebih luas. Mempertahankan pasar yang sudah ada dan mencari pasar yang baru dengan meningkatkan kesempatan promosi dengan mengikuti pameran yang ada.

2. Menjalin kerjasama dengan lembaga terkait untuk menabah modal usaha dan swalayanswalayan untuk memasarkan produk, serta mengurus izin kesehatan agar pemasaran keripik jahe lebih luas.

3. Menjaga ketersediaan bahan baku pada saat harga fluktuatif dan melakukan kontinitas produk dengan menyediakan stok bahan baku dan menghindari bahan baku yang terlalu lama disimpan.

4. Meningkatkan standar mutu bahan baku utama, bahan baku penunjang agar tidak mudah rusak, serta mencari informasi pasar melalui koran, dinas perdagangan dan mengikuti pameran yang ada, membuat produk yang lebih baik agar mampu memenuhi permintaan pasar, membuat produk yang lebih baik agar mampu memenuhi permintaan pasar.

\section{KESIMPULAN DAN SARAN}

\section{Kesimpulan}

Hasil penelitian dapat di simpulkan sebagai berikut : Strategi pengembangan yang tepat bagi pengrajin keripik jahe adalah Meningkatkan produksi keripik jahe untuk memenuhi permintaan pasar, melakukan promosi keripik jahe dan membuat kemasan yang lebih menarik agar dapat memasuki pasar yang lebih luas. Mempertahankan pasar yang sudah ada dan mencari pasar yang baru dengan meningkatkan kesempatan promosi dengan mengikuti pameran yang ada. Menjalin kerjasama dengan lembaga terkait untuk menabah modal usaha dan swalayan-swalayan untuk memasarkan produk, serta mengurus izin kesehatan agar pemasaran keripik jahe lebih luas. Menjaga ketersediaan bahan baku pada saat harga fluktuatif dan melakukan kontinitas produk dengan menyediakan stok bahan baku dan menghindari bahan baku yang terlalu lama disimpan. Meningkatkan standar mutu bahan baku utama, bahan baku penunjang agar tidak mudah rusak, serta mencari informasi pasar melalui koran, dinas perdagangan dan mengikuti pameran yang ada, membuat produk yang lebih baik agar mampu memenuhi permintaan pasar.

\section{Saran}

1. Bagi pemerintah perlu ditingkatkan dan diperbanyak pembekalan-pembekalan bagi pengusaha agroindustri berupa pelatihan- 
pelatihan sehingga pengusaha agroindustri dapat menerima informasi dan teknologiteknologi baru yang dapat mendukung kegiatan produksi usaha mereka.

2. Pengusaha sebaiknya memiliki izin usaha, agar produk keripik jahe dapat lebih leluasa memasuki pasar yang lebih besar dan agar keripik jahe lebih dikenal oleh konsumen.

3. Usaha jaheku khususnya dan masyarakat Desa Kota Raya pada umumnya diharapkan untuk mulai mengembangkan produk keripik jahe sebagai bentuk diversifikasi produk olahan jahe sehingga dapat meningkatkan pendapatan.

4. Perlu adanya sosialisasi yang lebih mendalam agar produk baru yaitu keripik jahe dapat lebih dikembangkan lagi sehingga dapat meningkatkan kesejahteraan masyarakat.

\section{DAFTAR PUSTAKA}

Lestari W. M.2006. Analisis finansial agroindustri aren (arenga pinnata) di Kabupaten Rokan Hulu Provinsi Riau. Skripsi Fakultas PertanianUniversitas Riau, Pekanbaru. (Tidak dipublikasikan).

Rangkuti, Freddy. 1997. Analisis SWOT. Tehnik membedah kasus bisnis. PT Gramedia Pustaka Utama, Jakarta.

Soekartawi. 2001. Pengantar Agroindustri. PT Raja Grafindo Persada. Jakarta.

Soekartawi. 2005. Agroindustri dalam perspetif sosial ekonomi.PT Raja Grafindo Persada. Jakarta.

Sudarsono, J. 2002. Pengantar Ekonomi Perusahaan. PT Prenhallindo. Jakarta.

Susilo, Eko Hadi. 2008. Strategi Pengembangan Agroindustri Kelapa SkalaKecildi Kabupaten Indragiri Hilir Provinsi Riau. Skripsi MahasiswaJurusan Sosial Ekonomi Pertanian. Universitas Riau. Pekanbaru. (TidakDipublikasikan). 
